\title{
História e Ficção em Call of Duty 3
}

Autor: Renato Ismael Pospich Pereira

Orientador: Prof. Ms. Jocelito Zalla

Resumo: Esta apresentação comunica os resultados de pesquisa realizada no Colégio de Aplicação da UFRGS sobre o jogo de videogame Call of Duty 3 (que narra os principais fatos da II Guerra Mundial). A minha pergunta inicial foi: Call of Duty 3 é baseado em fatos reais e por quê? Eu escolhi este projeto porque ganhei o jogo e fiquei curioso quanto à sua narrativa. Pesquisei na internet informações sobre a II Guerra Mundial e li um livro sobre o assunto. Depois, pude comparar os dados com as fases do jogo. O conceito de verossimilhança, que significa "ilusão de verdade", me ajudou a pensar se os elementos do jogo são ou não baseados em fatos reais. $\mathrm{O}$ jogo é inspirado em batalhas muito importantes da história da II Guerra, como a Operação Cobra, que foi um ataque aos nazistas (seu objetivo era fazer os nazistas irem para a Normandia, e foi um sucesso). $\mathrm{O}$ fato foi representado na narrativa do jogo de um modo um pouco diferente da realidade, pois a guerra não é narrada na íntegra, já que partes dela haviam sido tratadas em versões anteriores (Call of Duty 1 e 2). Os veículos, as armas e os terrenos de guerra são inspirados nos eventos reais, mas os personagens são fictícios e alguns lugares não foram representados fielmente, o que pude comprovar comparando fotos e vídeos da época com as imagens do jogo. De qualquer forma, a narrativa é verossímil, porque parece real ao jogador, como se reproduzisse a história da II Guerra.

Palavras-chave: Ficção; Jogos; Narrativa; Realidade;

Verossimilhança. 